\title{
Orgaandonatie na euthanasie: juridische overwegingen en vraagstukken
}

\author{
Mr. drs. J.A.M. Bollen, prof. dr. L.W.E. van Heurn, prof. dr. D. Ysebaert, prof. dr. W.N.K.A. van Mook \\ $\mathcal{E}$ mr. dr. M.M. ten Hoopen*
}

\section{Inleiding}

Terwijl euthanasie ethisch en juridisch gezien nog steeds tot discussies leidt, gaan de ontwikkelingen door. Er dienen zich situaties aan die nog een dimensie aan het euthanasievraagstuk toevoegen. Dit werd een aantal jaren geleden duidelijk toen de eerste gevallen in het nieuws kwamen van patiënten die de wens hadden om, na een door hen te ondergane euthanasie, één of meer organen te doneren. Zorgaanbieders en -verleners kwamen voor de vraag te staan of dit wel mogelijk is. Aanvankelijk was de reactie in de praktijk terughoudend. Onbekendheid met de procedure bracht onzekerheid mee over de implicaties ervan, zowel medisch-technisch als in ethische en juridische zin. ${ }^{1}$ Vergeleken met de lange tijd die nodig was voor de aanvaarding van de mogelijkheid van euthanasie, heeft het echter relatief kort geduurd voordat de combinatie euthanasie-orgaandonatie haar weg vond naar de medische praktijk. Het bleek niet nodig om de wetgeving aan te passen. Ook zal een rol hebben gespeeld dat euthanasie en orgaandonatie in Nederland geen nieuwe rechtsfiguren meer zijn; alleen de samenloop van beide brengt een verandering met zich mee.

In 2012 werd de gecombineerde euthanasie-orgaandonatieprocedure in ons land voor het eerst uitgevoerd. In 2005 was zij al in België toegepast. Sindsdien neemt het aantal procedures per jaar toe. Eind 2018 hadden in Nederland al vijftig patiënten organen gedoneerd na euthanasie. Hoewel het over de jaren heen gezien in beide landen dus om meerdere gevallen gaat, zal het totale aantal situaties waarin euthanasie en orgaandonatie in combinatie plaatsvinden in absolute zin wellicht beperkt blijven. Een patiënt die euthanasie zal ondergaan dient in de eerste plaats medisch geschikt te zijn voor het doneren van organen. Indien men lijdt aan een maligniteit wordt orgaandonatie onmogelijk, en ook de leeftijd speelt een rol. Met name patiënten die lijden aan een neurodegeneratieve ziekte, zoals multiple sclerose (MS), amyotrofische laterale sclerose (ALS) of de ziekte van Huntington zijn in beginsel geschikt om als donor te fungeren. De tot nu toe beschikbare cijfers over de

* Jan Bollen is jurist en aios anesthesiologie aan het Maastricht Universitair Medisch Centrum. Ernst van Heurn is hoogleraar Kinderchirurgie aan het Medisch Centrum Amsterdam. Dirk Ysebaert is hoogleraar Transplantatiechirurgie aan het Universitair Ziekenhuis Antwerpen. Walther van Mook is hoogleraar Professionele Ontwikkeling i.h.b. Intensive Care aan het Maastricht Universitair Medisch Centrum. Rankie ten Hoopen is universitair docent Gezondheidsrecht bij de Faculteit der Rechtsgeleerdheid, Universiteit Maastricht en juridisch medewerker bij Boels Zanders Advocaten te Maastricht.

1 J. Bollen, R. ten Hoopen, D. Ysebaert, et al., 'Legal and ethical aspects of organ donation after euthanasia in Belgium and the Netherlands', J Med Ethics 2016;42(8):486-489. doi: 10.1136/medethics-2015-102898. 
resultaten van transplantaties die plaatsvonden na een gecombineerde euthanasie-donatieprocedure zijn gunstig, maar nog vrij beperkt voorhanden. ${ }^{2}$

Uit eerder onderzoek van geanonimiseerde Belgische euthanasiedata blijkt dat 10,2\% van alle patiënten die op medische gronden euthanasie ondergaan in aanmerking zou kunnen komen voor orgaandonatie. ${ }^{3}$ Niet iedere patiënt binnen deze groep zal ook orgaandonor willen zijn, ook omdat hij dan voorbereidende onderzoeken dient te ondergaan en zal moeten overlijden in het ziekenhuis. Dit neemt niet weg dat een euthanasieprocedure die gevolgd wordt door orgaandonatie een bijdrage kan leveren aan het beschikbaar komen van organen voor patiënten die op een donororgaan zijn aangewezen. Orgaandonatie na euthanasie kan de periode bekorten waarin transplantatiepatiënten op een wachtlijst staan.

Een tweede positief effect van de combinatie euthanasie-orgaandonatie is dat zij de wens in vervulling kan doen gaan van patiënten die aan het einde van hun leven graag nog iets voor een ander betekenen.

In dit laatste schuilt juridisch en ethisch gezien echter juist ook een gevaar. De wilsverklaring gericht op euthanasie mag niet beïnvloed worden door de wil om nog iets goeds te doen voor een ander. Zij moet in vrijheid tot stand komen. Dit geldt ook omgekeerd, voor de arts die te maken heeft met een patiënt die een euthanasiewens heeft en tegelijkertijd een (potentiële) kandidaat voor donatie is. Hoe kan vermenging van belangen worden voorkomen? Daarnaast doen verdere ontwikkelingen, zoals organ donation euthanasia (ODE), vragen rijzen. Deze vragen zien met name op de afbakening van de gevallen waarin euthanasie te combineren is met donatie. Van ODE is sprake indien de patiënt niet overlijdt door de euthanasiemedicatie, maar door het uitnemen van organen, inclusief het hart, nadat hij zijn bewustzijn heeft verloren door de toepassing van anesthesie (zie nader par. 4.8$){ }^{4}$

In dit artikel staan de hiervoor genoemde aspecten en vragen betreffende orgaandonatie na euthanasie centraal. Het is niet de bedoeling om de relevante gezichtspunten uitputtend in kaart te brengen, maar wel om een goed beeld te geven van het onderwerp vanuit zowel een medische als een juridische invalshoek.

Eerst volgt een schets van het feitelijke verloop van de procedure waarbij zowel euthanasie als orgaandonatie plaatsvindt. Dit laat alvast zien waar medisch en juridisch gezien beslismomenten en mogelijke knelpunten liggen. Hierna komt aan de orde aan welke eisen de procedure van euthanasie en orgaandonatie dient te voldoen. Naast de wetgeving inzake euthanasie en orgaandonatie (de WOD in zijn huidige en zijn toekomstige vorm) staat de relevante zelfregulering (richtlijn inzake orgaandonatie na euthanasie) hier centraal. ${ }^{5}$ Vervolgens richt de aandacht zich op de kern van het onderwerp: de juridisch-ethische

2 D. Van Raemdonck, G.M. Verleden, L. Dupont, D. Ysebaert, D. Monbaliu, A. Neyrinck, W. Coosemans, H. Decaluwe, P. De Leyn, P. Nafteux, T. Lerut, 'Initial experience with transplantation of lungs recovered from donors after euthanasia', Applied Cardiopulmonary Pathophysiology 2011;15:38-48.

3 J. Bollen, T. van Smaalen, R. ten Hoopen, et al., 'Potential Number of Organ Donors After Euthanasia in Belgium', Jama 2017;317(14):1476-1477. doi: 10.1001/jama.2017.0729.

4 J.A.M. Bollen, D. Shaw, G. de Wert, et al., 'Euthanasia through living organ donation: Ethical, legal, and medical challenges', The Journal of heart and lung transplantation: the official publication of the International Society for Heart Transplantation 2019;38(2):111-113. doi: 10.1016/j.healun.2018.07.014 [published Online First: 2018/09/11].

5 Richtlijn Orgaandonatie na Euthanasie, Nederlandse Transplantatiestichting, versie 1.2, november 2017, te raadplegen via www.transplantatiestichting.nl/bestel-en-download/richtlijn-orgaandonatie-na-euthanasie. 
dilemma's aangaande de gecombineerde procedure euthanasie-orgaandonatie. Deze dilemma's vormen ook het hoofdbestanddeel van de conclusie waarmee dit artikel wordt afgerond. Hoewel de ontwikkelingen in België omtrent orgaandonatie na euthanasie eveneens een beschouwing waard zijn, vormt de Nederlandse situatie bij de bespreking het uitgangspunt.

Het is van belang om op te merken dat de auteurs zich uitdrukkelijk niet willen uitspreken voor of tegen de combinatie van euthanasie en orgaandonatie. De intentie is vooral om de lezer te informeren over de procedure waarbij euthanasie wordt gevolgd door orgaandonatie. Wel wordt hier en daar een mogelijke (denk)richting aangegeven.

\section{Euthanasie en orgaandonatie: schets van de procedure}

De in 2017 tot stand gekomen Richtlijn orgaandonatie na euthanasie bestaat uit een deel met instructies voor de praktijk en een deel met achtergronden, waarin onder andere de ethische aspecten en wettelijke kaders van de gecombineerde procedure worden besproken. In deze paragraaf worden stapsgewijs de verschillende onderdelen belicht die noodzakelijk zijn om de procedure correct te kunnen uitvoeren. ${ }^{6}$

Door de behandelend arts dient vastgesteld te zijn, na het oordeel van de tweede onafhankelijke arts (meestal een SCEN-arts (Steun en Consultatie bij Euthanasie in Nederland)), dat aan alle zorgvuldigheidseisen voor euthanasie is voldaan. De behandelend arts is in dit geval doorgaans de huisarts met wie de patiënt een behandelingsovereenkomst heeft op basis van artikel 7:446 BW, of de verpleeghuisarts met wiens werkgever (het verpleeghuis) een behandelingsovereenkomst is gesloten. Indien er geen duidelijke contra-indicaties voor orgaandonatie bestaan, zoals een maligniteit, kan het verzoek tot orgaandonatie besproken worden. Dit dient op initiatief van de patiënt te gebeuren. Men tracht op deze manier de invloed te beperken die de wens tot orgaandonatie kan hebben op de euthanasiewens. Later in dit artikel wordt ingegaan op de vraag wat dit betekent voor de autonomie van de patiënt (par. 4.5).

Indien de wens van de patiënt tot orgaandonatie blijft bestaan na informatieverstrekking door de behandelend arts, neemt deze arts contact op met de transplantatiecoördinator en de donatie-intensivist van een universitair medisch centrum (UMC). Er dient dan onderzocht te worden of de patiënt op medische gronden een potentiële donor is en welke organen in aanmerking komen voor donatie. Er is toestemming van de patiënt nodig om de relevante medische gegevens te controleren, maar ook om enkele voorbereidende onderzoeken uit te voeren. Het gaat dan om onderzoek van urine en bloed, maar ook om beeldvormend onderzoek.

Het beeldvormend onderzoek wordt meestal uitgevoerd in het ziekenhuis op de dag van de procedure. Indien de uitslag daarvan geen bijzonderheden oplevert, gaat Eurotransplant op zoek naar potentiële ontvangers. Eurotransplant beheert de transplantatiewachtlijsten van acht Europese landen. De personen die in aanmerking komen voor transplantatie van een orgaan worden geïnformeerd en dienen zich alvast naar het ziekenhuis te begeven. Hoewel de patiënt die wil doneren te allen tijde vrij is om de procedure te staken, kan hij dus wel druk ondervinden indien hij erover wordt ingelicht dat er ontvangers voor zijn 
organen zijn gevonden en zijn benaderd. Er kan eventueel ook druk ontstaan om de procedure te annuleren en de euthanasie alsnog thuis te laten plaatsvinden indien blijkt dat er geen geschikte ontvangers gevonden werden.

In aanwezigheid van de naasten van de patiënt dient de arts het euthanaticum toe, conform de Richtlijn uitvoering euthanasie en hulp bij zelfdoding van de Koninklijke Nederlandse Maatschappij ter bevordering der Pharmacie (KNMP). Dit gebeurt in een patientenkamer dicht bij de operatiekamers, wat meestal impliceert: in een kamer op de intensivecareafdeling. Wanneer de circulatiestilstand intreedt, wordt er vijf minuten gewacht, de zogenoemde no touch-tijd, die ingevolge artikel 14 lid 1 WOD en het Modelprotocol Postmortale orgaan- en weefseldonatie in acht dient te worden genomen. ${ }^{7}$ Gedurende deze periode mogen er geen invasieve handelingen worden verricht bij de patiënt, opdat eventuele autoresuscitatie (waarbij de circulatie van de patiënt 'spontaan' herstart, ook aangeduid als het zogenoemde Lazarus syndroom) uitgesloten kan worden. Vervolgens kan het overlijden worden vastgesteld.

Daarna wordt de overledene zo snel mogelijk verplaatst naar de operatiekamer om de uitnameprocedure te starten. De circulatiestilstand vormt namelijk het begin van de zogenoemde warme-ischemietijd (de organen lijden aan zuurstoftekort), die men zo kort mogelijk wenst te houden. Omdat euthanasie een niet-natuurlijk overlijden is, behoort de officier van justitie (OvJ) toestemming te geven voor zowel de verplaatsing van de overledene als de orgaandonatie (art. 76 lid 1 jo. 2 Wet op de lijkbezorging). Daarom dient het te verwachten overlijden op voorhand gecommuniceerd te worden met de OvJ, opdat deze snel beschikbaar zal kunnen zijn. Ook de gemeentelijke lijkschouwer dient van tevoren geïnformeerd te worden, om op het betreffende moment aanwezig te kunnen zijn en snel een schouwing te kunnen uitvoeren.

Vervolgens worden de organen op aangeven van Eurotransplant vervoerd naar de ontvangers. Het is niet mogelijk voor de donor om op voorhand een ontvanger van een specifiek orgaan aan te duiden (zie nader par. 4.6).

\section{De voor de combinatie euthanasie-orgaandonatie relevante wet- en regelgeving}

\subsection{Euthanasie}

De patiënt die euthanasie wenst te ondergaan dient te voldoen aan de zorgvuldigheidseisen van artikel 2 WTL (Wet toetsing levensbeëindiging op verzoek en hulp bij zelfdoding). Daartoe behoort, naast de eis van uitzichtloos en ondraaglijk lijden, onder andere de eis van een vrijwillig en weloverwogen verzoek. De grootste uitdaging bij de gecombineerde euthanasie-orgaandonatieprocedure is de beoordeling van dit aspect. Er bestaat namelijk een kans dat de patiënt tot de wens komt om euthanasie te ondergaan wegens het feit dat hij dan in de mogelijkheid verkeert om zijn organen te doneren. Hoewel de patiënten die tot op heden de gecombineerde procedure hebben ondergaan zeer tevreden waren over het feit dat ze een positieve betekenis konden geven aan hun lijden, mag dit niet het (enige) motief zijn. Het euthanasieverzoek behoort voort te komen uit het uitzicht-

7 Gezondheidsraad, Modelprotocol Postmortale orgaan- en weefseldonatie, versie 1.1 - januari 2019, te raadplegen via www.transplantatiestichting.nl/sites/default/files/modelprotocol_postmortale_orgaan-_en_ weefseldonatie.pdf. 
loos en ondraaglijk lijden. Dit is meteen ook de reden waarom de Richtlijn orgaandonatie na euthanasie en de literatuur een strikte scheiding verlangen van de beide procedures. ${ }^{8}$ Het is aan de behandelend arts en de onafhankelijke arts (SCEN-arts) om een euthanasieverzoek waarbij de patiënt reeds over orgaandonatie spreekt kritisch te beoordelen.

In 2017 ondergingen 6.585 patiënten euthanasie, een aantal dat sinds de invoering van de WTL jaarlijks toeneemt. De regionale toetsingscommissies euthanasie (RTE's), die ex post beoordelen of een euthanasieprocedure zorgvuldig werd uitgevoerd, hebben tot op heden in hun uitspraken geen bezwaar geuit tegen procedures waarin de euthanasie werd gevolgd door orgaandonatie. Zelfs in een casus waarin de patiënt thuis gesedeerd en geïntubeerd werd voorafgaand aan vervoer naar het ziekenhuis waar vervolgens de euthanasie plaatsvond, volgde geen negatief oordeel. ${ }^{9}$

De RTE's publiceerden in 2018 een nieuwe euthanasiecode, de EuthanasieCode 2018, een leidraad voor euthanasieprocedures die de Code of Practice uit 2015 vervangt. ${ }^{10}$ Hierin wordt uitdrukkelijk gesteld dat de WTL geen uitspraken doet over wat er na euthanasie mag gebeuren met het lichaam. Wel wordt benadrukt dat de voorgenomen donatieprocedure de zorgvuldigheid van de euthanasieprocedure niet mag beïnvloeden.

\subsection{Orgaandonatie}

De Wet op de Orgaandonatie (WOD) maakt een onderscheid tussen het ter beschikking stellen van organen bij leven en het ter beschikking stellen van organen na overlijden. Binnen deze laatste categorie wordt er medisch gezien gesproken van donation after brain death (DBD) in het geval van hersendood, en van donation after circulatory death (DCD) nadat hartstilstand is ingetreden. Er bestaan volgens de medische literatuur vier categorieën DCD, die ook wel de 'Maastricht-classificaties' genoemd worden. Orgaandonatie na euthanasie wordt in deze context beschreven als een 'type 3', vergelijkbaar met de situatie waarin de behandeling van een patiënt die is opgenomen op de intensive care afdeling wordt gestaakt. $\mathrm{Na}$ het stopzetten van de levensondersteunende maatregelen kan orgaandonatie plaatsvinden indien de patiënt binnen twee uur overlijdt.

Ook uit de WOD zijn geen argumenten af te leiden die een barrière opwerpen tegen de combinatie met euthanasie. In deze gecombineerde procedure bestaat er zelfs een voordeel in vergelijking met DBD en DCD. In deze laatste gevallen is het namelijk de familie die, indien een registratie van de patiënt als donor ontbreekt, op een emotioneel moment gevraagd wordt of orgaandonatie kan plaatsvinden, aangezien de patiënt zelf op dat moment bewusteloos is. Indien de patiënt zich wél als orgaandonor heeft geregistreerd in het Donorregister, zal de familie daarover geïnformeerd worden en zal men de uitnameprocedure kunnen starten. In de praktijk wordt hiervan afgeweken indien de donatie op ernstige psychische of emotionele bezwaren van de familie stuit. $\mathrm{Nu}$ de patiënt bij orgaan-

8 J. Bollen, W. de Jongh, J. Hagenaars, et al., 'Organ Donation After Euthanasia: A Dutch Practical Manual', American journal of transplantation: official journal of the American Society of Transplantation and the American Society of Transplant Surgeons 2016;16(7):1967-1972. doi: 10.1111/ajt.13746.

9 Oordeel 2017-18, Regionale Toetsingscommissies Euthanasie, Te raadplegen: www.euthanasiecommissie.nl/ uitspraken/publicaties/oordelen/2017/consultatie/oordeel-2017-18.

10 Regionale Toetsingscommissies Euthanasie, EuthanasieCode 2018: De toetsingspraktijk toegelicht, april 2018, te raadplegen via www.euthanasiecommissie.nl/binaries/euthanasiecommissie/documenten/ brochures/brochures/euthanasiecode/2018/euthanasiecode2018/EuthanasieCode2018.pdf. 
donatie na euthanasie echter zelf, bij vol bewustzijn en met volle overtuiging, te kennen heeft gegeven dat hij orgaandonor wil zijn, zal de familie zijn wens in de regel respecteren. Vanaf 1 juli 2020 zal de nieuwe wetgeving gaan gelden waarmee de huidige WOD wordt gewijzigd. ${ }^{11}$ In het dan in te voeren actieve donorregistratiesysteem (ADR) is iedereen een potentiële orgaandonor, tenzij men een weigering heeft laten registreren. Wie, ondanks een verzoek daartoe per brief en een herinneringsbrief, geen keuze heeft gemaakt (bestaande uit: 1. Ja, ik geef toestemming; 2. Nee, ik geef geen toestemming; 3. Mijn partner of familie beslist; 4. De door mij gekozen persoon beslist), zal worden geregistreerd met de aanduiding 'Geen bezwaar'. Toestemming voor donatie wordt dan verondersteld, zolang er geen gebruik is gemaakt van de mogelijkheid om alsnog een keuze te maken en de registratie te wijzigen. Uiteindelijk hebben echter ook in dit systeem familieleden een bepaalde, laatste stem. ${ }^{12,13}$

De minister van Volksgezondheid, Welzijn en Sport (VWS) heeft in een brief van september 2017 aan de Eerste Kamer gesteld dat de nieuwe registratiesystematiek geen gevolgen heeft voor de procedure van orgaandonatie na euthanasie, aangezien het gaat om een bewuste en nadrukkelijke keuze van de patiënt. ${ }^{14}$ Ook eerder al, toen de Richtlijn inzake orgaandonatie na euthanasie nog in ontwikkeling was, had de minister zich positief uitgelaten over de gecombineerde procedure naar aanleiding van Kamervragen van de Kamerleden Tellegen en Arib. ${ }^{15}$

\subsection{Euthanasie in combinatie met orgaandonatie}

Evenals bij DBD en DCD kunnen er bij orgaandonatie na euthanasie voorbereidende handelingen uitgevoerd worden. Denk aan onderzoek dat noodzakelijk is voor de voorbereiding van de transplantatie, zoals onderzoek van bloed en urine, maar ook beeldvormend onderzoek (art. 20 jo. 22 WOD). Het is vervolgens mogelijk om longen, nieren, lever en pancreas te doneren.

Op 12 december 2018 publiceerde de Gezondheidsraad een advies over het vaststellen van de dood bij orgaandonatie na euthanasie, naar aanleiding van een adviesaanvraag van de minister van VWS. De conclusie van een door de Gezondheidsraad ingestelde commissie is dat er geen reden is om voor deze specifieke procedure af te wijken van het 'normale' vaststellen van de dood bij postmortale orgaandonatie, zoals hiervoor beschreven. Opvallend is echter dat men adviseert om desgewenst een arteriële lijn te plaatsen bij de patiënt. Er wordt dan een soort infuus geplaatst in de slagader in de pols die op de monitor een curve weergeeft wanneer het hart bloeddruk creëert.

De auteurs zijn het om verschillende redenen, en vanuit praktische ervaringen, oneens met dit advies. Het plaatsen van een arterielijn kan - ook wanneer de eerste poging daartoe

11 J.K.M. Gevers, 'De herziening van de Wet op de orgaandonatie: een terugblik', TvGR 2018, p. 387-400.

12 Kamerstukken I, 33506, Initiatiefvoorstel-Pia Dijkstra over het opnemen van een actief donorregistratiesysteem, te raadplegen via www.eerstekamer.nl/wetsvoorstel/33506_initiatiefvoorstel_pia.

13 E.J.O. Kompanje, 'Automatische Donor Registratie: een ultieme poging om meer witte raven te vangen?', Tijdschrift Zorg \& Recht in praktijk 1 (januari 2017), p. 15-19.

14 Brief van de minister van Volksgezondheid, Welzijn en Sport inzake het voorstel van wet van het lid Pia Dijkstra tot wijziging van de Wet op de orgaandonatie in verband met het opnemen van een actief donorregistratiesysteem, Kamerstukken I 2017/18, 33506, K, te raadplegen via www.eerstekamer.nl/behandeling/ 20170921/brief_van_de_minister_van_vws_ter/document3/f=/vkhubdf94hlh.pdf.

15 Antwoorden op Kamervragen van Arib en Tellegen, 2015Z02563 en 2015Z02564, 4 maart 2015. 
slaagt - door de patiënt namelijk als pijnlijk worden ervaren en daardoor voor deze een (extra) belasting opleveren. De lijn kan bovendien niet meer losgekoppeld worden, waardoor de patiënt minder mobiel is dan later wellicht wenselijk is. Ook is de uitvoerend arts meestal een huisarts, en daarmee iemand die in het algemeen geen ervaring heeft met het plaatsen of analyseren van een arterielijn. Het zal hierdoor nodig zijn om gebruik te maken van de hulp van een intensivist of anesthesioloog, en de patiënt zal moeten overlijden op bijvoorbeeld een intensivecareafdeling waar de technische mogelijkheden voor de noodzakelijke monitoring beschikbaar zijn. De commissie noemt als argument voor het aanbrengen van de lijn dat hierdoor de warme-ischemietijd zo veel mogelijk beperkt kan worden. Dit lijkt echter ook mogelijk te zijn wanneer de circulatiestilstand en het overlijden op de conventionele manier (door de pols te voelen of naar de hartslag te luisteren) vastgesteld worden. ${ }^{16}$ Gelet op het principe van de autonomie van de patiënt zou de te volgen werkwijze in ieder geval aan de patiënt uitgelegd kunnen worden, zodat hij hierover zelf zou kunnen beslissen.

\section{Juridische en ethische vraagstukken}

\subsection{Nadere beschouwingen}

Vanuit juridisch perspectief lijkt er geen bezwaar te zijn tegen de combinatie van euthanasie en orgaandonatie. De relevante wetgeving bevat, zoals ook hiervoor opgemerkt, geen elementen die deze procedure verbieden. Hierbij verdient wel aantekening dat de wetgever, de laatste wijziging van de WOD daargelaten, waarschijnlijk geen rekening heeft gehouden met een samengaan van euthanasie en orgaandonatie. Aannemelijk is dat hij deze combinatie niet heeft voorzien. Dit neemt niet weg dat er juridisch gezien aspecten zijn die aandacht vragen en dat ook ethisch nog de nodige vragen rijzen.

\subsection{Toepasselijkheid van de Wkkgz en verantwoordelijkheid van het ziekenhuis}

De patiënt wordt op de dag van de euthanasie- en donatieprocedure opgenomen in een ziekenhuiskamer nabij de operatiekamers. Meestal voert de (verpleeg)huisarts de euthanasie uit, hoewel deze geen vaste relatie heeft met het ziekenhuis. De patiënt zal in de regel immers niet willen dat een in het ziekenhuis werkzame medisch specialist de euthanasie verricht nu een vertrouwensband met deze persoon ontbreekt, tenzij zich de situatie zich voordoet dat de medisch specialist zélf langere tijd bij zijn behandeling betrokken is geweest. Een specialist die verbonden is aan het ziekenhuis zal in het algemeen ook niet díe - meer intensieve - behandelrelatie met de patiënt hebben die in een euthanasiecasus vereist is.

$\mathrm{Nu}$ de (verpleeg)huisarts bepaalde verrichtingen in het ziekenhuis uitvoert zonder dat hij daar op basis van een arbeidsovereenkomst werkzaam is, zal het ziekenhuis (Raad van Bestuur) op grond van artikel 4 lid 1 onder b Wkkgz (Wet kwaliteit, klachten en geschillen zorg) met hem een schriftelijke overeenkomst van opdracht (toelating) moeten sluiten. Wij nemen hierbij aan dat dit vereiste, gezien de (ruime) strekking van de Wkkgz om de kwali-

16 Gezondheidsraad, Vaststellen van de dood bij postmortale orgaandonatie, 10 juni 2015, te raadplegen via www.gezondheidsraad.nl/documenten/adviezen/2015/06/10/vaststelling-van-de-dood-bij-postmortaleorgaandonatie. 
teit van de zorg te waarborgen, ook geldt in de onderhavige situatie, ook al is daarin sprake van een eigen, zelfstandige rol van de huisarts bij de euthanasie. Niet overtuigend lijkt ons de opvatting dat niet gesproken zou kunnen worden van 'zorg doen verlenen' door het ziekenhuis (als zorgaanbieder) in de zin van artikel 4 lid 1 onder b Wkkgz. ${ }^{17}$

In de bedoelde overeenkomst zal onder meer de verplichting moeten zijn opgenomen dat de (verpleeg)huisarts zich bij zijn werkzaamheden laat leiden door de op het ziekenhuis rustende wettelijke verplichtingen (denk vooral aan de verplichtingen uit de Wkkgz) en de regels die intern in het ziekenhuis gelden ('huisregels'). Dit houdt verband met het feit dat het ziekenhuis op grond van de Wkkgz eindverantwoordelijk is voor de kwaliteit van de zorg, met inbegrip van de zorg die ad hoc door de (verpleeg)huisarts wordt verstrekt.

Een aanname bij het voorgaande is dat de handelingen die de (verpleeg)huisarts in het kader van de euthanasie verricht zijn te kwalificeren als 'zorg' in de zin van artikel 1 lid 1 Wkkgz. Zij vormen, doordat euthanasie onder het basispakket van de Zvw valt (zorgverzekeraars kunnen deze prestatie in hun modelovereenkomsten overigens wel van vergoeding uitsluiten, zie art. 11 lid $5 \mathrm{Zvw}$ ), namelijk 'Zvw-zorg'. Ook lijkt te kunnen worden aangehaakt bij de in artikel 1 lid 1 Wkkgz vermelde categorie 'andere zorg'. Een vérgaande oprekking van de wettelijke terminologie is hiervoor niet nodig, aangezien de hiervoor al genoemde strekking van de Wkkgz (kwaliteitswaarborging) aanleiding geeft om het begrippenpaar 'andere zorg' niet al te strikt te interpreteren en daaronder óók de 'bijzondere zorg' te scharen die bij euthanasie wordt verleend.

\subsection{Toepasselijkheid van afdeling 7.7.5 BW en civielrechtelijke aansprakelijkheid van het ziekenhuis}

Privaatrechtelijk rijst de vraag of het ziekenhuis centraal aansprakelijk kan worden gesteld, op basis van artikel 7:462 BW, bij tekortschietend handelen van de (verpleeg)huisarts. Dit is in beginsel het geval, omdat sprake is van een situatie waarop de regeling van de centrale aansprakelijkheid ziet (arts out-situatie). Tussen het ziekenhuis en de arts bestaat immers géén arbeidsrechtelijke verhouding (arts in-situatie). In dit laatste geval is er de facto overigens ook sprake van een 'centrale' aansprakelijkheid, maar dan op grond van artikel 6:76 en 6:170 BW doordat de arts contractueel gezien als een hulppersoon van het ziekenhuis is te beschouwen en buitencontractueel als diens ondergeschikte.

Aansprakelijkstelling is eventueel denkbaar ter verhaal van immateriële schade van de nabestaanden van de patiënt. Per 1 januari 2019 kan dat in beginsel ook affectieschade zijn. Op vragen die de recente wijziging van artikel 6:106-108 BW in dit kader kunnen doen rijzen wordt in dit artikel niet ingegaan. ${ }^{18}$

Een belangrijke voorvraag die het voorgaande oproept, is of bij het toepassen van euthanasie wel een geneeskundige behandelingsovereenkomst tussen de (verpleeg)huisarts en de patiënt tot stand komt, dan wel of een reeds bestaande behandelingsovereenkomst zich ook tot de fase van de euthanasie-orgaandonatie uitstrekt. Indien dit niet zo is, kan artikel 7:462 BW geen toepassing vinden en vervalt de mogelijkheid tot centrale aansprakelijkstelling van het ziekenhuis. De klassieke, door Leenen geformuleerde opvatting is dat

17 Een andere opvatting is mogelijk (de tekst is weinig helder en lijkt zichzelf tegen te spreken) af te leiden uit Nederlandse Transplantatiestichting, Richtlijn Orgaandonatie na euthanasie, Deel 2, Achtergronden, p. 55. 
euthanasie geen 'gewoon' medisch handelen is. ${ }^{19}$ Het betreft namelijk geen 'handeling op het gebied van de geneeskunst' zoals in artikel 7:446 lid 2 BW omschreven. Daardoor ontbreekt één van de kernvereisten waaraan moet worden voldaan om een overeenkomst als 'overeenkomst inzake geneeskundige behandeling' te kunnen betitelen in de zin van artikel 7:446 lid $1 \mathrm{BW}$. Leenens argumenten zijn vooral gebaseerd op de parlementaire geschiedenis van afdeling 7.7.5 BW. Hij leidt daaruit onder andere af dat de wetgever bij de totstandbrenging van artikel 7:446 lid $2 \mathrm{BW}$ niet aan euthanasie heeft gedacht. Consequent doorredenerend acht hij ook analoge toepassing van afdeling 7.7.5 BW met gebruikmaking van de schakelbepaling van artikel 7:464 lid 1 BW niet mogelijk nu ook deze bepaling uitgaat van 'handelingen op het gebied van de geneeskunst'.

In reactie op een discussiestuk van Arends in het Tijdschrift voor Gezondheidsrecht (2017) sluit Sijmons zich bij deze visie van Leenen aan..$^{20,} 21$ Ook hij doet een beroep op de wetsgeschiedenis. Zijn kernargument is hierbij dat een contractuele gebondenheid van de arts, met een verplichting tot nakoming in de vorm van het uitvoeren van de euthanasie, zich niet verdraagt met het bijzondere karakter van euthanasie: de arts moet tot op het laatste moment de vrijheid (kunnen) behouden om zijn geweten te volgen en zich eventueel terug te trekken. De overeenkomst tussen partijen zou dan ook nietig zijn ingevolge artikel 3:40 lid $1 \mathrm{BW}$ wegens strijd met de goede zeden. Sijmons ziet wel ruimte voor analoge toepassing van afdeling 7.7.5 BW, via artikel 7:464 lid $1 \mathrm{BW}$, op de 'schil' van handelingen om de euthanasie heen, zoals de keuze en het verschaffen van het euthanaticum en de verslaglegging in het medisch dossier. Het door hem daarvoor genoemde argument is dat de betreffende handelingen sterk in de sfeer van de geneeskunde liggen.

Arends neemt het standpunt in dat euthanasie tegenwoordig tot het reguliere medische domein behoort, waardoor de regels betreffende de overeenkomst van opdracht en, meer specifiek, die inzake de geneeskundige behandelingsovereenkomst van toepassing zijn. ${ }^{22}$ Uit de wetsgeschiedenis van afdeling 7.7.5 BW zou juist volgen dat de wetgever alle door artsen verrichte handelingen onder de omschrijving handelingen op het gebied van de geneeskunst' heeft willen brengen.

Met betrekking tot de combinatie euthanasie-orgaandonatie stelt Sijmons, in lijn met zijn hiervoor weergegeven zienswijze, dat het ziekenhuis niet op grond van artikel 7:462 BW hoofdelijk aansprakelijk is te stellen voor verrichtingen die door de huisarts, met gebruikmaking van de ziekenhuisfaciliteiten, bij de euthanasie zijn uitgevoerd. Centrale aansprakelijkstelling van het ziekenhuis zou evenmin mogelijk zijn voor de handelingen van de huisarts om de euthanasie heen ('schil'), omdat artikel 7:462 BW niet - via artikel 7:464 lid $1 \mathrm{BW}$, de bepaling waarbij in het geval van deze handelingen zou worden aangeknoopt - analoog zou kunnen worden toegepast. Wellicht berust deze opvatting op het feit dat artikel 7:462 BW een behandelingsovereenkomst tussen de hulpverlener (in casu:

19 Zie ook H.J.J. Leenen e.a., Handboek gezondheidsrecht (zevende druk), Den Haag: Boom juridisch 2017, p. 64, p. 103 en hoofdstuk 5.

20 L.A.P. Arends, 'Discussie: euthanasie onder de WGBO. I De euthanasieovereenkomst: non-existent of een juridische werkelijkheid?', TvGR 2017, p. 399- 405. Zie ook 'Vervolg discussie: euthanasie onder de WGBO. Naschrift L.A.P. Arends', TvGR 2017, p. 566-569.

21 J.G. Sijmons, 'Discussie: euthanasie onder de WGBO. II De onmogelijke euthanasieovereenkomst: geen geneeskundige behandelingsovereenkomst', TvGR 2017, p. 406-410. Zie ook 'Vervolg discussie: euthanasie onder de WGBO. Naschrift J.G. Sijmons', TvGR 2017, p. 569-571.

22 L.A.P. Arends, 'Discussie: euthanasie onder de WGBO', TvGR 2017, p. 399-405. 
de (verpleeg)huisarts) en de patiënt veronderstelt, in de nakoming van welke overeenkomst de hulpverlener toerekenbaar is tekortgeschoten.

Wij sluiten ons aan bij de visie van Sijmons dat bij euthanasie geen sprake is van een overeenkomst inzake geneeskundige behandeling, omdat deze visie onzes inziens het meest strookt met de wetsgeschiedenis en met het karakter van euthanasie. Euthanasie is, naar onze opvatting, nog steeds als een gebeurtenis en een verrichting van bijzondere aard aan te merken. Wel lijkt ons een tweetal kanttekeningen bij Sijmons' benadering op zijn plaats. De eerste kanttekening is of de omweg van artikel 7:464 lid $1 \mathrm{BW}$ wel nodig is om afdeling 7.7.5 BW van toepassing te doen zijn op de handelingen rondom de euthanasie-donatieprocedure ('schil'). Men kan beargumenteren dat deze handelingen geen 'geneeskunst' zijn omdat ze niet ten voordele noch ter genezing van de donerende patiënt worden uitgevoerd. Men kan eveneens stellen dat ze één geheel vormen met de euthanasie als zodanig en juridisch daarom op dezelfde wijze als de euthanasie (geen 'geneeskunst') dienen te worden gekwalificeerd. Wanneer men echter toch ook gewicht toekent aan het feit dat ze in de sfeer van de geneeskunde liggen, en men ze bij de toepassing van artikel 7:464 lid $1 \mathrm{BW}$ (kennelijk) schaart onder de in dit artikel genoemde 'handelingen op het gebied van de geneeskunst' (vergelijk Sijmons), is de stap naar kwalificatie als 'handelingen op het gebied van de geneeskunst' in de zin van artikel 7:446 lid 1 en 2 BW klein. Het resultaat zou dan zijn dat bepalingen zoals artikel 7:453 en 454 BW (goed hulpverlenerschap, dossierplicht) alsmede artikel 7:462 BW rechtstreeks - niet analoog - zijn toe te passen op de verrichtingen van de (verpleeg)huisarts rondom de euthanasie-orgaandonatie. Dit zou de rechtsbescherming van de patiënt, in ieder geval de duidelijkheid daarover (geen constructie via artikel 7:464 lid 1 BW; zie met betrekking tot artikel 7:462 BW ook de tekst hierna), ten goede kunnen komen. Een voordeel zou ook zijn dat de verrichtingen in de 'schil' rond de euthanasie op deze wijze eenzelfde kwalificatie ten deel zou vallen als de handelingen ter voorbereiding van de orgaandonatie. Die zijn gezien hun medische aard namelijk rechtstreeks (zonder de omweg van art. 7:464 lid $1 \mathrm{BW}$ ) te duiden als handelingen op het gebied van de geneeskunst. Verder ontstaat er meer parallellie met de publiekrechtelijke benadering in het kader van de Wkkgz; denk aan de ruime omschrijving en invulling van het begrip 'zorg' in artikel 1 lid 1 Wkkgz (zie par. 4.2).

De tweede kanttekening betreft Sijmons' (kennelijke) aanname dat artikel 7:462 BW zich niet voor analoge toepassing via artikel 7:464 lid $1 \mathrm{BW}$ leent. De strekking van artikel 7:464 lid 1 BW lijkt ruimte te bieden voor een andere, ruimere, opvatting. Zouden, evenals bijvoorbeeld de patiënt die bewusteloos het ziekenhuis wordt binnengebracht (met eventueel een te verwachten donatieprocedure), de nabestaanden van de patiënt bij wie iets mis is gegaan bij de verrichtingen rondom de euthanasie-donatieprocedure geen gebruik moeten kunnen maken van de voordelen van de regeling van de centrale ziekenhuisaansprakelijkheid? Het eventuele alternatief, dat van een beroep op artikel 3:33 jo. 3:35 BW (behandelrelatie met het ziekenhuis op grond van door het ziekenhuis opgewekt vertrouwen) is juridisch weinig beproefd en daarom niet aantrekkelijk.

De praktijk leert dat ziekenhuizen uit vrees voor een mogelijke centrale aansprakelijkheid nogal eens terughoudend zijn bij het toelaten van de (verpleeg)huisarts voor het uitvoeren van de euthanasie voorafgaand aan de orgaandonatie. Uit het voorgaande volgt dat deze vrees niet gegrond is indien wordt uitgegaan van de visie van Sijmons (de handelingen in de schil rond de euthanasie daargelaten), wél als wordt aangesloten bij de zienswijze van 
Arends. De vraag is hierbij of het aansprakelijkheidsrisico wel zo groot is nu relatief (zeer) weinig euthanasiecasussen door de regionale toetsingscommissies als onzorgvuldig worden beoordeeld en dit tot nu toe ook het beeld is bij de combinatie euthanasie-orgaandonatie. Bovendien zouden ziekenhuisbestuurders vooral ook oog dienen te hebben voor de aanmerkelijke belangen van niet-financiële aard aan de zijde van de patiënt.

\subsection{Strafrechtelijke aansprakelijkheid}

Indien de regionale toetsingscommissie in een bepaald geval wél van oordeel is dat de euthanasie onzorgvuldig werd uitgevoerd, kan het Openbaar Ministerie besluiten om tot vervolging over te gaan. De rechter zou vervolgens tot het oordeel kunnen komen dat de uitvoerend arts schuldig is aan het beëindigen van iemands leven op diens uitdrukkelijk en ernstig verlangen (art. $293 \mathrm{Sr}$ ).

Theoretisch gezien zouden de bij de euthanasie betrokken zorgverleners alsook het ziekenhuis (als rechtspersoon) en één of meer van zijn bestuurders medeplichtig kunnen zijn (art. 51 lid 1 en 2 Sr). Zij zijn dan namelijk opzettelijk behulpzaam geweest bij het plegen van een misdrijf, of zij hebben hiertoe opzettelijk gelegenheid of middelen verschaft (art. 48 Sr). Volgens artikel 49 lid 4 Sr komen voor het bepalen van de straf alleen die handelingen in aanmerking die de medeplichtige opzettelijk gemakkelijk heeft gemaakt of bevorderd, benevens hun gevolgen. Waar het deze gevolgen betreft, is niet relevant of het opzet daar mogelijkerwijze niet op was gericht.

De Hoge Raad verlangt dat er sprake is van zogenoemd 'dubbel opzet' en er dus opzet is gericht op het leveren van een bijdrage én op het strafbare feit. Bij euthanasie gevolgd door orgaandonatie leveren zowel het ziekenhuis als de zorgverleners een bijdrage aan de benodigde handelingen die op dat moment tezamen nog als een strafbaar feit zijn te beschouwen, hoewel eenieder vertrouwt op de correcte toepassing van de zorgvuldigheidseisen door de uitvoerend (verpleeg)huisarts. Het is in de praktijk belangrijk dat men er inderdaad op kan vertrouwen dat deze arts een correcte afweging heeft gemaakt, zodat in een voorkomend geval alleen híj ex post strafrechtelijk aansprakelijk kan worden gesteld. De in paragraaf 4.2 besproken (toelatings)overeenkomst tussen het ziekenhuis en de (verpleeg)huisarts kan een instrument zijn om op voorhand bepaalde kwalificaties vast te leggen waaraan de (verpleeg)huisarts moet voldoen, zoals deskundigheid en ervaring met betrekking tot de euthanasie- en eventueel ook de donatieprocedure.

Mede gelet op de mogelijke juridische implicaties is het niet vreemd dat ziekenhuizen reeds commissies hebben ingericht die de euthanasievraag van een patiënt, wanneer die gecombineerd is met orgaandonatie, een tweede keer beoordelen. Hierdoor werden zelfs al euthanasieverzoeken afgewezen. Het is begrijpelijk dat ziekenhuizen zich wensen in te dekken, maar men lijkt zich zo te bemoeien met de arts-patiëntrelatie en de autonome beslissing die de uitvoerend arts, geadviseerd door de SCEN-arts, bij euthanasie neemt. De gevolgde werkwijze is hierdoor moeilijk te verenigen met het bepaalde in de WTL. Bovendien kan men zich afvragen of zij de mate van verantwoordelijkheid niet juist 'vergroot' in die gevallen waarin de procedure tóch als onzorgvuldig wordt beoordeeld door de regionale toetsingscommissie. 


\subsection{Autonomie van de patiënt}

Orgaandonatie na euthanasie wordt door zorgverleners ondersteund en gefaciliteerd opdat de laatste wens van de patiënt ingewilligd kan worden. Tegelijkertijd wordt een positief resultaat bereikt voor een patiënt die op de transplantatiewachtlijst staat. Toch bestaat er nog verschil van opvatting aangaande de informatieplicht jegens de patiënt.

Op basis van artikel 7:448 BW dient een hulpverlener de patiënt altijd correct te informeren over de voorgestelde behandeling. Het is echter onduidelijk of het noodzakelijk is om de patiënt ook te informeren over de mogelijkheid tot orgaandonatie, ook na euthanasie. Bij de combinatie orgaandonatie-euthanasie dient immers extra zorgvuldig te worden gehandeld om te vermijden dat de patiënt zich onder druk gezet voelt om in te stemmen of mogelijk zelfs de indruk krijgt dat hij (eerder) in aanmerking komt voor euthanasie omdat hij zijn organen zal doneren. Tegelijkertijd kunnen familieleden na het overlijden - of ook de patiënt zelf indien hij dit ontdekt vóór de euthanasie - ontevreden zijn over het niet vermelden van de mogelijkheid tot orgaandonatie na euthanasie. Illustratief voor deze laatste situatie is, zij het buiten het terrein van orgaandonatie na euthanasie (een onverwacht overlijden na kort tevoren ontstane fysieke klachten) een recent door het Tuchtcollege Den Haag beoordeelde casus. Onbekendheid met de donatiewens van de patiënt en onbekendheid van de doodsoorzaak - orgaandonatie is dan in beginsel niet mogelijk - maakten in dit geval dat het tuchtcollege geen verwijtbaar handelen aanwezig achtte bij de huisarts van de betrokken patiënt. ${ }^{23}$

Volgens het principe van autonomie kan de patiënt slechts een weloverwogen besluit nemen indien hij correct en voldoende geïnformeerd is. Toch lijkt terughoudendheid noodzakelijk in deze zeer gevoelige context. De huidige richtlijn inzake orgaandonatie na euthanasie stelt dat de patiënt zelf het voorstel tot orgaandonatie na euthanasie dient te uiten. Indien dit gebeurt voordat het besluit aangaande honorering van het euthanasieverzoek is genomen, behoort de arts het gesprek over dit onderwerp uit te stellen totdat duidelijk is dat aan de zorgvuldigheidseisen van artikel 2 lid 1 onder a-e WTL wordt voldaan. Wij zijn van mening dat een arts die deze duidelijkheid heeft verkregen het Donorregister behoort te raadplegen. Deze verplichting kan ook gelezen worden in artikel 20 lid 1 WOD dat bepaalt dat men in geval van een gerede kans op overlijden binnen afzienbare tijd dient na te gaan of in het Donorregister een wilsverklaring van de betreffende persoon is te vinden.

Op basis van deze wilsverklaring en de relatie die de arts met de patiënt heeft kan de arts - indien er op dat moment geen contra-indicaties voor orgaandonatie zijn - al dan niet het initiatief nemen om de patiënt te informeren over de mogelijkheid tot orgaandonatie. Zelfs wanneer er een weigering geregistreerd staat, zou het naar onze mening gelegitimeerd kunnen zijn om met de patiënt het gesprek aan te gaan. De omstandigheden, en daarop gestoelde gedachten van de patiënt, kunnen immers geheel anders zijn dan die welke de patiënt ten tijde van het invullen van het donorformulier voor ogen had. De landelijke richtlijn inzake orgaandonatie na euthanasie stelt daarentegen expliciet dat de huisarts niet actief de mogelijkheid van orgaandonatie na euthanasie mag benoemen. 


\subsection{Gekozen ontvanger(s)}

De argumentatie om orgaandonatie na euthanasie mogelijk te maken steunt vooral op het beginsel van autonomie, gecodificeerd in artikel $11 \mathrm{GW}$ en ten grondslag liggend aan zowel afdeling 7.7.5 BW als de WOD. Mensen moeten in beginsel te allen tijde zelf over hun lichaam kunnen beschikken, en dus ook de mogelijkheid hebben om hun organen te doneren indien zij voor euthanasie kiezen. Deze lijn doortrekkend kan men ook stellen dat zij de ontvanger(s) van hun organen behoren te kunnen kiezen.

Indien de patiënt die euthanasie wenst een persoon kent die, bijvoorbeeld, een nieuwe nier nodig heeft, dan zou hij bij leven een nier kunnen afstaan aan die persoon, op voorwaarde dat dit orgaan medisch geschikt blijkt voor de ontvanger, ook wat betreft de compatibiliteit (de mate waarin de organen qua weefseltypering overeenkomen). Bij een donatie na overlijden behoort de toewijzing van het orgaan echter te verlopen via het orgaancentrum, zoals bepaald in artikel 18 jo. $24 \mathrm{WOD}$, en wordt de keuze voor een bepaalde persoon of personen als ontvanger(s) niet overgelaten aan de donor. Zoals eerder is besproken door Sijmons, weerspiegelt zich hierin een stelsel van collectief beschikken over organen van een overledene, en niet een individueel beschikken. ${ }^{24} \mathrm{Het}$ zou echter zeer onwenselijk zijn als een patiënt die een nier wil doneren aan een specifieke persoon eerst nog bij leven een ingreep zou moeten ondergaan om dit te realiseren alvorens euthanasie te ondergaan en dan zijn overige organen aan onbekenden te doneren.

Het verdient daarom aanbeveling om ook déze vorm van zelfbeschikking wettelijk te faciliteren. Een regel die het - ook buiten de combinatie met euthanasie - mogelijk maakt om iemand aan te duiden voor het ontvangen van één of meer van zijn organen zal ook in algemene zin bemoedigen tot het doneren van organen op een moreel niet-aanvechtbare wijze. Dit zal echter wel spanning oproepen met het principe van een rechtvaardige verdeling van organen. Gezien dit belangrijke nadeel ligt het in de rede om het toepassingsgebied van een dergelijke regel te beperken tot alleen die patiënten die in een bijzondere situatie (euthanasie) nog iets voor een ander willen betekenen, om zo hun bijzondere wensen in vervulling te kunnen laten gaan en wellicht ook de nabestaanden te sterken op een moeilijk moment.

\subsection{De minderjarige patiënt}

Ook een minderjarige heeft vanaf de leeftijd van 12 jaar wettelijk gezien de mogelijkheid om euthanasie te ondergaan. Hiervoor dient hij aan dezelfde zorgvuldigheidseisen te voldoen als een volwassene. Indien de minderjarige de leeftijd heeft tussen de 12 en 16 jaar dienen de ouders zich met de levensbeëindiging te kunnen verenigen. Indien hij tussen 16 en 18 jaar oud is, dienen de ouders bij de besluitvorming te worden betrokken (art. 2 lid 3 jo. 4 WTL).

Daarnaast kunnen kinderen van 12 jaar of ouder toestemming geven voor het verwijderen van hun organen na overlijden (art. 9 lid 1 WOD). Er is dus ook geen wettelijk beletsel tegen het uitvoeren van orgaandonatie na euthanasie bij minderjarigen vanaf 12 jaar. Theoretisch zou een ouder nog bezwaar kunnen uiten na het overlijden van de minderjarige patiënt jonger dan 16 jaar, maar uitsluitend vóór het uitnemen van de organen (art. 12 
WOD). Aangezien er in deze leeftijdscategorie echter ook toestemming van de ouders vereist is voor euthanasie, lijkt dit slechts een hypothetische situatie.

Ook hier neemt de juridische basis niet weg dat het een ethisch en emotioneel zeer gevoelige kwestie is, aangezien alleen al euthanasie bij kinderen vaak moeilijk te aanvaarden is. Toch zou de laatste, weloverwogen wens van de minderjarige patiënt om zijn organen te doneren gefaciliteerd moeten kunnen worden. ${ }^{25}$ Er dient hierbij wel opgemerkt te worden dat euthanasie bij minderjarigen heel beperkt voorkomt, en dan met name in geval van een maligniteit. Deze patiënten komen bijgevolg niet in aanmerking voor orgaandonatie.

Soms wordt discussie gevoerd over de vraag of euthanasie ook mogelijk dient te zijn voor kinderen jonger dan 12 jaar. Het is af te wachten hoe de gedachten hierover zich verder ontwikkelen en wat de eisen voor deze categorie dan zouden worden, en ook wat dit zou betekenen voor orgaandonatie na euthanasie bij kinderen. ${ }^{26}$

\subsection{Organ donation euthanasia}

Een potentieel toekomstig dilemma betreft de procedure die in de internationale literatuur ook wel wordt aangeduid met de term organ donation euthanasia (ODE). De patiënt overlijdt dan niet door de euthanasiemedicatie, maar krijgt anesthesie alvorens de organen, inclusief het hart, worden uitgenomen, hetgeen dan het overlijden veroorzaakt. Deze procedure wordt op dit moment ethisch gezien nog als een stap te ver beschouwd.

Vanzelfsprekend is voor ODE slechts plaats indien aan de zorgvuldigheidseisen die gelden voor euthanasie wordt voldaan, en indien de patiënt weloverwogen besluit tot orgaandonatie. De vraag om deze procedure uit te voeren is inmiddels al daadwerkelijk door patiënten geuit in de voorbereidende gesprekken rondom orgaandonatie na euthanasie. Hierdoor zouden de organen namelijk in betere staat zijn én is het mogelijk om ook het hart te doneren, iets wat door de donoren belangrijk gevonden wordt, respectievelijk waarom men verzoekt.

Aangezien de patiënt nog leeft wanneer de organen verwijderd worden, dient gesproken te worden over het ter beschikking stellen van organen bij leven. De wet stelt echter duidelijk dat orgaandonatie bij leven die gevolgen heeft voor de gezondheid van de donor slechts mogelijk is indien de ontvanger van 'het' orgaan in levensgevaar verkeert en dit gevaar niet op andere wijze even goed kan worden afgewend (art. 5 lid 1 WOD). Hoewel er nog gediscussieerd zal kunnen worden over het in levensgevaar zijn van een persoon op de transplantatiewachtlijst, heeft de wetgever zich duidelijk gericht op het doneren van één orgaan. In de huidige praktijk gaat het dan meestal over nierdonatie. In de hypothetische situatie van ODE speelt hiernaast dus de gezondheid van de donor een rol bij het doneren van alle mogelijke organen en weefsels.

Er dient geconcludeerd te worden dat ODE momenteel juridisch niet toegestaan is. Door veranderingen in de praktijk van orgaandonatie zal wellicht wel nagedacht moeten worden over wijziging, te zijner tijd, van de wetgeving en daarmee samenhangende richtlijnen aan de nieuwe ontwikkelingen, tenminste wanneer daar voldoende politiek, maatschappe-

25 J.A.M. Bollen, R. ten Hoopen, M.A.H.B.M. van der Hoeven, D. Shaw, J. Brierley, D. Ysebaert, L.W.E. van Heurn, W.N.K.A. van Mook, 'Organ donation after euthanasia in children: Belgian and Dutch perspectives', Archives of Disease in Childhood, augustus 2018, doi: 10.1136/archdischild-2018-315560.

26 O.A. Meijer, 'Wilsbekwaam maar te jong? Over euthanasie bij wilsbekwame kinderen jonger dan twaalf jaar' TvGR 2016, p. 466-477. 
lijk, juridisch en ethisch draagvlak voor bestaat. De benodigde aanpassing van de WOD is nog niet opgenomen in de wetswijziging (introductie ADR-stelsel) die in 2020 zal ingaan, maar kan mogelijk voor een eerste keer besproken worden bij de wetsevaluatie in 2023. ${ }^{27}$ In ieder geval moet vermeden worden dat het brede publiek de indruk krijgt dat er een 'jacht' op organen bestaat, waarbij zelfs vitale organen kunnen worden uitgenomen bij een levende patiënt. Dit druist in tegen de huidige dead donor rule, die het belang van de donor wenst te beschermen.

\section{Conclusie}

Orgaandonatie na euthanasie is voor patiënten met een euthanasiewens en daarnaast de wens om nog iets voor één of meer anderen te kunnen betekenen een waardevolle procedure. Voor patiënten op een wachtlijst voor transplantatie is ieder (extra) orgaan dat ter beschikking komt levensreddend. De wetgeving verzet zich niet tegen een combinatie van beide procedures, zelfs niet bij minderjarigen vanaf 12 jaar. Hierdoor heeft deze combinatie de afgelopen jaren in toenemende mate ingang gevonden in de medische praktijk. Zij werd in Nederland al minstens vifftig keer uitgevoerd. Er dient echter verder gedebatteerd te worden over de juridisch-ethische dilemma's rondom orgaandonatie na euthanasie, zoals het informeren van de patiënt die euthanasie zal ondergaan over de mogelijkheid tot orgaandonatie en het uitnemen van de organen bij een patiënt onder algehele anesthesie (ODE). Het is in dit kader uitermate belangrijk om het recht op autonomie van de patiënt te respecteren en zijn laatste wens waar mogelijk in te willigen. Nieuwe ontwikkelingen zoals ODE zullen in de toekomst aanleiding kunnen zijn om de wetgeving (verder) te overdenken en mogelijk tot een wijziging daarvan over te gaan. 